Pasture Plants. In 1913, Norman was appointed entomologist to the Canadian government and they soon built him a laboratory on the Criddle farm. Norman published 125 papers about birds, mammals, flowers and especially insects, and studied the life cycle of more than 70 species of grasshopper. He had "remarkable biological judgement which was controlled by study and guided by a great breadth of mind nurtured upon wide and thoughtful reading in science, literature and art." No less an authority than Hoyes Lloyd stated in his obituary that "Canada in losing him has lost her best field-naturalist."

The entire family had an affinity for nature. Chickadees came and ate from their hands, and the book includes a photo of redpolls swarming over Maida. Percy's diaries recorded some firsts, including the first raccoon for the area in 1883 and the first house sparrow in 1897. However, this book tells us much more about the Criddles themselves than about their observations.

Additional research might have corrected a few omissions and errors. Although his knowledge of Canadian birds was decidedly limited, Percy began sending migration dates to Washington in 1884, a fact omitted from this book. Norman was an Associate of the American Ornithologists' Union, not a counsellor and Past President, an error which was copied from his obituary in the Canadian Entomologist.

We owe Alma Criddle a debt of gratitude for her skillful use of Percy and Norman Criddle's diaries as the main source of material for this book. Carol Scott provided the initial encouragement for writing it, and the surviving members of the family contributed their reminiscences.

The unusual title of the book, Criddle-de-diddle-enis, is explained in chapter 19. In 1883, Percy Criddle was visited by English naturalist and author R. Miller Christy, and his young friend Ernest E. Thompson (Seton). These men admired Percy's already creditable butterfly collec- tion. After their departure, Per humourously recorded in his dia that his "new friends anticipate brilliant future and immortality, o ing to my possible discovery of sor new insect or other in this une plored district which will be of cout called Criddle-de-diddle-ensis some other fancy family name."

This interesting book may be $c$ tained through the Blue Bookshop, Box 1121, Regina. -C. Houston, 863 University Dr., Sast toon, Saskatchewan S7J 0J8.

\section{THE AMERICAN ROBIN}

\section{A Backyard Institution}

LEN EISERER, with line drawings $b$ Martha R. Hall. 1976. Nelson Hall I Publishers, $325 \mathrm{~W}$. Jackson Blvd., Chicago 60606. 165 pp. \$12.50 US.

This book is a readable descript of the life style and natural histor) the American Robin. The feeling the author and others who strive live in harmony with the nat world is well expressed in the ded tion, "To Robins everywhere, they may continue to prosper bey the human reckoning of time, and California Condors, that they forgive us for what we have don

Under the heading "Hey, Wa That a Robin?" Chapter 1 descr the range of the robin's contact human beings in North Americ various times of the year and various geographical locations. following chapters treat differer between the six races of rob migration to nesting areas, and st of the life cycle, again with spe reference to contact with hu beings and their "nests" "territories".

The diet of robins is discusse detail, with particular regard variations at different times of year and stages of maturity fledglings. The fact that robins cultivated fruit is discussed sa without accepting all the claim crop damage that are made. 
The discussion of robin behaviour cludes group roosting, territorial lerance on feeding grounds, hanges of behaviour at different asons of the year and overwinterg. The care of injured birds is eated briefly.

The author's clear style, not irdened with excessive detail, akes his book readable from Grade level up. His reference to studies of e natural history of robins inspire e reader's confidence. There are veral colour photographs of robins nestlings, juveniles and adults ese are excellent. But the use of very wide margins in the text seems a waste of paper hardly in keeping with thrift in use of natural resources.

By its general tone, this book emphasizes the sacredness of life and the fragility of the relationship between human beings and the wild animals which we meet at close range. It repeatedly conveys the thought expressed in the final chapter in the description of a young robin shot by a boy with an air rifle, "A little lame Robin who lived in the hands of human compassion but died at the hands of human callosity." - J. R. Jowsey, 2635 - 19th Ave., Regina, Saskatchewan S4T 1X2

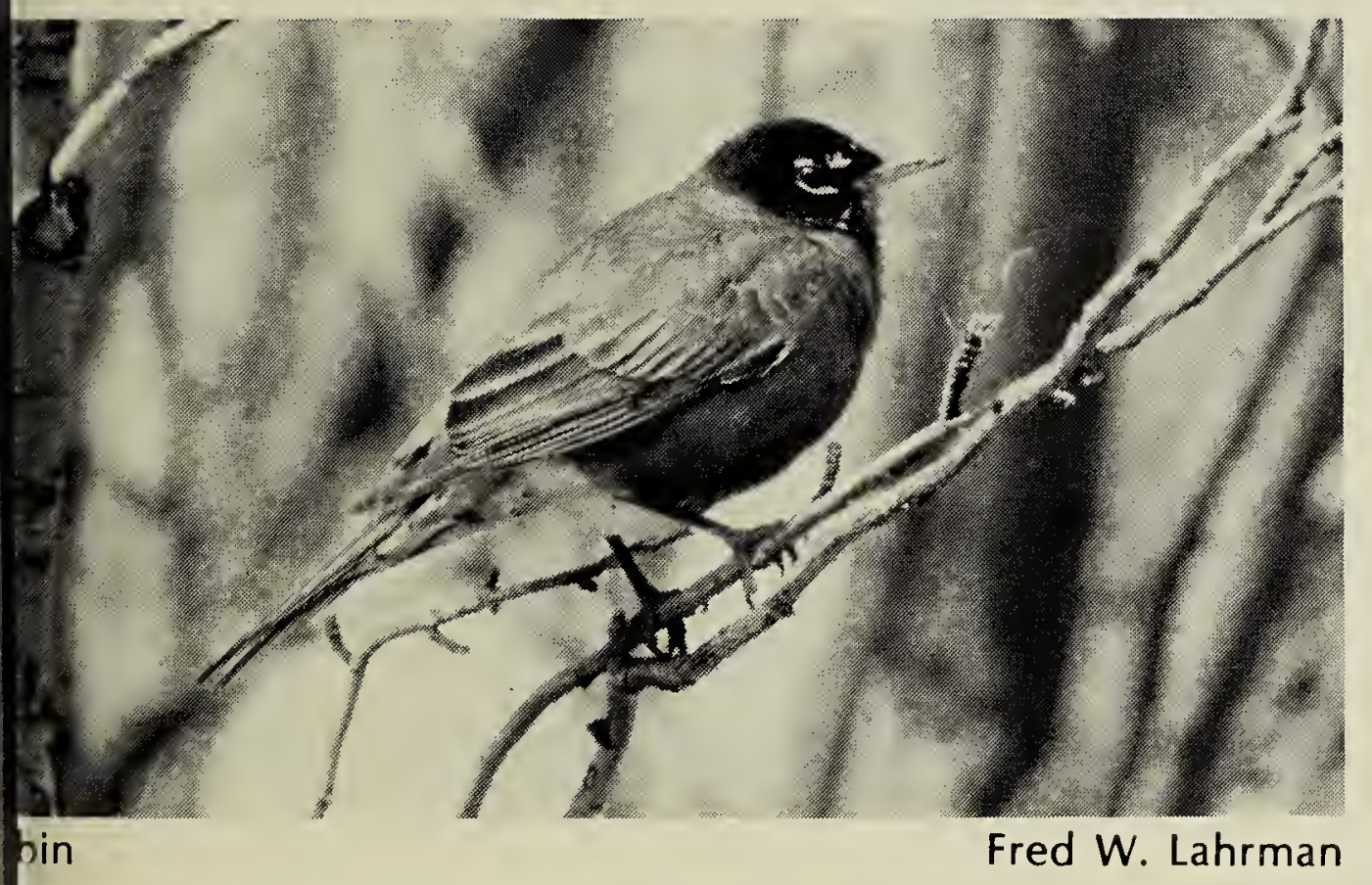

\section{VAILABLE FOR YOUR FORMATION ...}

TRESPASSING - the proceedings a seminar held by the Conservation uncil of Ontario on the problems public access to private land. The page booklet is available from the uncil office at 45 Charles Street t, Toronto, Ontario M4Y 1S2, for 50.

U AND PESTICIDE USE - a new mphlet available from the Plant Hustry Branch, Saskatchewan partment of Agriculture, Room , Administration Building, Regina OB1.

VIRONMENTAL ADVISORY UUNCIL 1976 ANNUAL REPORT - a 21 page report outlining the activities of the Council during the past year. Available from the Council at Sub P.O. Box 40, Regina, Saskatchewan.

THE RECLAMATION STORY - a glossy, 12 page brochure that tells the story of the Saskatchewan Power Corporation's efforts at reclaiming strip mined land in the Estevan area. Available from SPC Head Office, Regina, Saskatchewan.

LAND FOR WILDLIFE AND PEOPLE an attractive brochure that introduces Manitoba's Wildlife Management Areas. Available from the Department of Renewable Resources and Transportation Services, Box 22, 1495 St. James Street, Winnipeg, Manitoba R3H 0W9. 